\title{
Articles
}

\section{National Higher Courts and European Integration: A Survey of Six Decades of Academic Inquiry}

\author{
By Pablo José Castillo Ortiz ${ }^{*}$
}

\begin{abstract}
Boosted by landmark decisions such as Crotty, Solange, or Maastricht-Urteil, academic literature on National Higher Courts in the context of European integration has undergone an exponential growth in the last decades. In this Article, I aim at mapping this emerging subfield in order to explore the three patterns that structure it. First, a trend towards the consolidation and expansion of literature on the higher courts of the Member States, which has gained relative autonomy from general studies on European law and politics. Second, a clear tendency towards the internationalization of this subfield, which has developed in parallel to the national scholarship on the topic. And third, the emergence of a pattern of transdisciplinary dialogue in a subfield featured by the diversity of approaches, methodologies, and epistemological backgrounds.
\end{abstract}

* Lecturer in Law at the University of Sheffield, United Kingdom. PhD in Law and Political Science (Universidad Autónoma de Madrid, Spain). Specialist in Judicial Politics and processes of regional integration, with a focus on the European Union. Contact: p.castillo-ortiz@sheffield.ac.uk. 


\section{A. Introduction}

Although the European Court of Justice reigns supreme as the most researched judicial institution in European Union studies, it is now widely accepted that some of the most important rulings issued over various decades of European integration have been made by National Higher Courts (NHCs). The Solange saga ${ }^{1}$ by the German Federal Constitutional Court is one of the earliest examples of the so-called judicial dialogue with the Court of Justice, and changed the way in which inter-court relations had been understood in the European Communities up to then. The Maastricht-Urteil decision, ${ }^{2}$ in which the doctrine Kompetenz-Kompetenz was fully developed, had an enormous academic impact, and the scholarly debate to which it gave rise still endures. ${ }^{3}$ More recently, with their decisions on the instruments to deal with the Euro-crisis, ${ }^{4}$ the higher courts of the Member States once again have showed their capacity to intervene in processes with far-reaching political implications at the European level. These decisions are, however, just a small sample of the whole population of rulings of NHCs on European Union law, which also includes all those

\footnotetext{
${ }^{1}$ See Bundesverfassungsgericht [BVerfGE] [Federal Constitutional Court], May 29, 1974, 37 ENTSCHEIDUNGEN DES BUNDESVERFASSUNGSGERICHTS 271; Bundesverfassungsgericht [BVerfGE] [Federal Constitutional Court], Oct. 22, 1986, 73 ENTSCHEIDUNGEN DES BUNDESVERFASSUNGSGERICHTS 339.

${ }^{2}$ See Maastricht-Urteil, Bundesverfassungsgericht [BVerfG] [Federal Constitutional Court], October 12, 1993, 2 BVR 2134 et seq.

${ }^{3}$ See generally Julio Baquero, The Legacy of the Maastricht-Urteil and the Pluralist Movement, 14 EUR. L.J. 389 (2008); Christoph Schönberger, Lisbon in Karlsruhe: Maastricht's Epigones at Sea, 10 GermAN L.J. 1201 (2009).

4 See Consiel constitutionnel [CC] [Constitutional Court] decision No. 2012-653DC, Aug. 9, 2012 (Fr.); Verfassungsgerichtshof [VfGH] [Constitutional Court], Apr. 3, 2013, ERKENNTNISSE UND BESCHLÜSSE DES VERFASSUNGSGERICHTSHOFES [VFSLG] No. 2/12 (Austria); Estonian Supreme Court, decision No. 3-4-1-6-12 ESM Treaty I, 12 July 2012; Bundesverfassungsgericht [BVerfGE] [Federal Constitutional Court], Sept. 7, 2011, 2 BVR 987/10; Bundesverfassungsgericht [BVerfGE] [Federal Constitutional Court], Sept. 12, 2012, 2 BVR 1390/12; Pringle v. The Gov't of Ireland [2012] IESC 47 (SC) (Ir.); Bundesverfassungsgericht [BVerfG] [Federal Constitutional Court], Mar. 18, 2014, 2 BVR 1390/12.
} 


\author{
on European Union treaties, ${ }^{5}$ cases on the implementation of secondary law of the $\mathrm{EU},{ }^{6}$ or \\ even more recently, on austerity measures. ${ }^{7}$
}

The salience of these rulings was from the outset paralleled by a growing body of scholarly production. Lawyers, but also political scientists and sometimes even sociologists and

${ }^{5}$ For an additional case to the Maastricht-Urteil ruling, see, e.g., Bundesverfassungsgericht [BVerfG] [Federal Constitutional Court], July 30, 1952, 1 BvG 396; Crotty v. An Taoiseach [1987] IESC 4 [1987] IR 713 (SC) (Ir.); Consiel constitutionnel [CC] [Constitutional Court] decision No. 92-312DC, Apr. 9, 1992 (Fr.); Consiel constitutionnel [CC] [Constitutional Court] decision No. 92-312DC, Sept. 2, 1992 (Fr.); Consiel constitutionnel [CC] [Constitutional Court] decision No. 92-313DC, Sept. 23, 1992 (Fr.); S.T.C., July 1, 1992 (No. 001/1992) (Spain); Danish Supreme Court, case UfR 1998, 800 Maastricht, decision of 6 April 1998; Consiel constitutionnel [CC] [Constitutional Court] decision No. 97-394, Dec. 31, 1997 (Fr.); Consiel constitutionnel [CC] [Constitutional Court] decision No. 92-312, Nov. 19, 2004 (Fr.); S.T.C., Dec. 13, 2004 (No. 1/2004) (Spain); Verfassungsgerichtshof [VfGH] [Constitutional Court] June 18, 2005, ERKENNTNISSE UND BESCHLÜSSE DES VERFASSUNGSGERICHTSHOFES [VFSLG] No. G 62/05 (Austria); Slovakian Constitutional Court, case II. U.S. 171/05-175 Constitutional Treaty, decision of 27 February 2008; Consiel constitutionnel [CC] [Constitutional Court] decision No. 2007-560, Dec. 20, 2007 (Fr.); Nález Ústavního soudu ze dne 30.09.2008 (ÚS) [Decision of the Constitutional Court of Sept. 30, 2008], sp.zn. ÚS 19/08 publ. in: Sbírka nálezů a usnesení Ústavního souda (Czech); Nález Ústavního soudu ze dne 03.11.2009 (ÚS) [Decision of the Constitutional Court of Nov. 2, 2009], sp.zn. ÚS 29/09 publ. in: Sbírka nálezů a usnesení Ústavního souda (Czech); Latvian Constitutional Court, case 200835-01 Treaty of Lisbon, decision of 7 April 2009; Bundesverfassungsgericht [BVerfG] [Federal Constitutional Court], June 30, 2009, 1 BVE 2/08; Cour Constitutionelle [CC] [Constitutional Court] decision no 58/2009, Mar. 19, 2009, Moniteur BeLGe [MB] [Official Gazette of Belgium] (Belg.); Cour Constitutionelle [CC] [Constitutional Court] 125/2009, July 16, 2009, M.B. (Belg.); Polish Constitutional Court, case K32/09 Treaty of Lisbon, decision of 23 November 2010; Verfassungsgerichtshof [VfGH] [Constitutional Court] Sept. 30, 2008, ERKENNTNISSE UND BESCHLÜsSE DES VERFASSUNGSGERICHTSHOFES [VFSLG] No. SV 2/08-3 (Austria); Verfassungsgerichtshof [VfGH] [Constitutional Court] Sept. 30, 2008, ERKENNTNISSE UND BeSCHLÜSSE DES VERFASSUNGSGERICHTSHOFES [VFSLG] No. 80/08-3 (Austria); Verfassungsgerichtshof [VfGH] [Constitutional Court] Sept. 30, 2008, ERKENNTNISSE UND BESCHLÜSSE DES VERFASSUNGSGERICHTSHOFES [VFSLG] No. G SV 3/08-6 (Austria); Verfassungsgerichtshof [VfGH] [Constitutional Court] Sept. 30, 2008, ERKENNTNISSE UND BESCHLÜSSE DES VeRFASSUNGSGERICHTSHOFES [VFSLG] No. G 81/08-6 (Austria); Verfassungsgerichtshof [VfGH] [Constitutional Court] Sept. 30, 2008, ERKENNTNISSE UND BESCHLÜSSE DES VERFASSUNGSGERICHTSHOFES [VFSLG] No. SV 3/08-6 (Austria); Verfassungsgerichtshof [VfGH] [Constitutional Court] Sept. 30, 2008, ERKENNTNISSE UND BESCHLÜSSE DES VERFASSUNGSGERICHTSHOFES [VFSLG] No. 81/08-6 (Austria); Verfassungsgerichtshof [VfGH] [Constitutional Court] Mar. 11, 2009, ERKENNTNISSE UND BESCHLÜSSE DES VERFASSUNGSGERICHTSHOFES [VFSLG] No. G 149-152/08-5 (Austria); Cour Constitutionelle [CC] [Constitutional Court] decision no 156/2009 Treaty of Lisbon III, Oct. 17, 2008; Slovenian Constitutional Court, case UI-49/08 Treaty of Lisbon, decision of 17 October 2008; Verfassungsgerichtshof [VfGH] [Constitutional Court] June 12, 2010, ERKENNTNISSE UND BESCHLÜSSE DES VERFASSUNGSGERICHTSHOFES [VFSLG] No. SV 1/10-9 (Austria).

${ }^{6}$ See, e.g., Alkotmánybíróság (AB) [Constitutional Court] May 25, 2004, 17/2004 (Hung.); Polish Constitutional Court, Case P 1/05), decision of 27 April 2005; Supreme Court of Cyprus, case 294/2005, decision of 7 November 2005; Bundesverfassungsgericht [BVerfG] [Federal Constitutional Court], July 18, 2005, 1 BVR 2236/04; Slovakian Constitutional Court, case PI US 8/04-202, decision of 18 October 2005; Polish Constitutional Court, case U 6/08, decision of 17 December 2009; Polish Constitutional Court, case SK 26/08, decision of 5 October 2010.

${ }^{7}$ Austerity measures were usually passed by national authorities, but they are no doubt part of the more general European management of the crisis. See Portuguese Constitutional Court, case 353/2012, decision of 5 July 2012. Portuguese Constitutional Court, case 187/2012, decision of 5 April 2013. S.T.C., Dec. 18, 2004 (No. 215/2014) (Spain).; S.T.C., Oct. 23, 2014 (No. 171/2014) (Spain); Cristina Fasone, Constitutional Courts Facing the Euro Crisis: Italy, Portugal and Spain in a Comparative Perspective (Eur. Univ. Inst. Max Weber Programme, Working Paper No. MWP 2014/25, 2014). 
historians, seemed to understand the core role that NHCs were starting to play in the integration of the continent. Research on their decisions was marked by the variety of approaches, ranging from doctrinal interpretations, ${ }^{8}$ to analysis of their normative and philosophical implications, ${ }^{9}$ to empirical explanations of judicial decision-making, ${ }^{10}$ to theorizations of the strategies followed by courts in their relations with the Court of Justice, ${ }^{11}$ to networks and transnational legal activity. ${ }^{12}$ This Article reviews approximately 150 pieces of research on this area, which will show that slowly, but progressively, a whole subfield was born. This subfield was rooted in a variety of academic disciplines and with the role of NHCs in the process of European integration at its core.

In this Article, I shall aim at mapping this subfield, analyzing academic literature on NHCs in the process of European integration and describing the main patterns and trends that crosscut it. My focus will be essentially, although not only, English language literature, and my objective will be to summarize various decades of academic production and to identify the direction towards which current research moves. In so doing, I aim at contributing to the self-awareness of this body of literature, as at this point of its process of maturation it can already construct a narrative about its history and undertake a reflection about its present situation and future challenges. In particular, I shall argue that three patterns can be identified in the subfield. First, as suggested above, the increasing attention devoted by scholarly literature on European Union studies to NHCs, which points towards the emergence and consolidation of a subfield of research. Second, a trend towards the institutionalization of an internationalized body of scholarly production, through the creation of a transnational network of academics for whom the decisions of their NHCs on

${ }^{8}$ See, e.g., Petr Bř́za, The Czech Republic. The Constitutional Court on the Lisbon Treaty: Decision of 26 November 2008, 5 EUR. CONST. L. REV. 143 (2009); Jan Komarek, The Czech Constitutional Court's Second Decision on the Lisbon Treaty of 3 November 2009, 5 EUR. CONST. L. REV. 345 (2009).

${ }_{9}^{9}$ See, e.g., Neil MacCormick, The Maastricht-Urteil: Sovereignty Now, 1 EUR. L.J. 259 (1995); Joseph H.H Weiler, Does Europe Need a Constitution? Demos, Telos and the German Maastricht Decision, 1 EUR. L.J. 219 (1995).

${ }^{10}$ See, e.g., Carlos Closa \& Pablo José Castillo Ortiz, National Courts and Ratification of European Union Treaties, in Multilayered Representation in the Eur. Union. Parlaments, Courts and the Pub. Sphere 129 (Tatjana Evas, Christopher Lord \& Ulrike Liebert eds., 2012); Carlos Closa, National Higher Courts and the Ratification of European

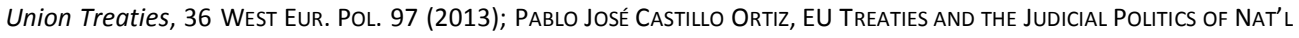
COURTS. A LAW ANd POLITICS APPROACH (2016).

11 See, e.g., Arthur Dyèvre, European Integration and National Courts: Defending Sovereignty Under Institutional Constraints?, 9 EUR. CONST. L. ReV. 139 (2013); Arthur Dyèvre, Judicial Non-Compliance in a Non-Hierarchical Legal Order: Isolated Accident or Omen of Judicial Armageddon? (2012) (revised Mar. 4, 2015), http://papers.ssrn.com/sol3/papers.cfm?abstract_id=2084639.

12 See Monica Claes \& Maartje de Visser, Courts United? On European Judicial Networks, in LAWYERING EUR. EUR. LAW as A TRansnational Soc. Field 75 (Antoine Vauchez \& Bruno de Witte eds., 2013); Monica Claes \& Maartje de Visser, Are You Networked Yet? On Dialogues in European Judicial Networks, 8 UTRECHT L. REV. 100 (2012); Simone Benvuti, National Supreme Courts and the EU Legal Order: Building a European Judicial Community Through Networking, 6 Perspectives on Federalism 1 (2014). 
European Union matters are not any longer an exclusively national issue. And third, a trend towards the diversification of approaches, in which legal-doctrinal analyses coexist with social sciences and even humanities ones. This final pattern points towards a rich academic scenario featured by a consolidated multidisciplinarity and an emerging interdisciplinarity. Academics from different disciplinary backgrounds seem to fully realize that they are not alone in the study of NHCs and often engage in mutual dialogue, even if truly interdisciplinary approaches are still a minority phenomenon. Consolidation, internationalization, and multidisciplinarity are, thus, the three defining features of a subfield which is probably to expand in the future as NHCs' involvement in European Union affairs is unlikely to decrease in the next years.

In order to explain these three patterns, this Article is structured as follows. After this introduction, I will briefly describe the evolution of the field of European judicial integration over the last decades, paying attention both to the preference for certain objects of study and to the disciplinary approaches that have structured scholarly production. Next, I will analyze the literature focusing on NHCs in the process of European integration. I will show how the different disciplines covering this topic have displayed different internal dynamics and differentiated theoretical and epistemological assumptions. Yet, in the following section I will show how, despite their differences, these varied disciplines have converged in the analysis of particular topics and objects of study, thus engaging in fruitful conversation. The Article finishes with some brief conclusions.

\section{B. The Role of NHCs in the Field of European Judicial Integration}

In the last decades, studies on European judicial and legal integration have gained autonomy from general studies in European integration and have emerged as a distinct field. Within this new field, the analysis of NHCs is one of the main provinces. As a result of the salience of their rulings, the higher courts of the Member States have been deemed to merit not only scholarly, but also social and political attention. In this context, the study of NHCs has emerged as a specific, semi-autonomous subfield, with its own dynamics and structuring patterns.

This, however, was not always the case. In fact, for the first decades of European integration $\mathrm{NHCs}$ had a rather marginal role in academic literature. It can be said that, at least until the 1980s, studies on judicial actors in the European Union were dominated by two main characteristics.

First, the preferential focus on the Luxembourg Court, with special emphasis on its jurisprudence. ${ }^{13}$ The attention paid to the NHCs in the European integration process was

\footnotetext{
${ }^{13}$ See Peter Hay, European Economic Community: Res Judiciata and Precedent in the Court of Justice of the Common Market, 12 AM. J. CoMP. L. 404 (1963); Roger-Michel Evallier, Methods and Reasoning of the European Court in its Interpretation of Community Law, 2 COMmon MKT. L. REV. 21 (1965); Stefan Riesenfeld, The Doctrine of Self-
} 
much smaller. It is true that certain national jurisprudence by national higher or lower courts was indeed occasionally studied, especially when it had any incidence for European law or affected the relationships with the Court of Justice, such as in the early works by Pappalardo, Alkema, or Berri. ${ }^{14}$ Furthermore, some studies do exist which refer to judicial interventions in processes of ratification of the treaties of the European Union. A good example is the excellent analysis of Karl Loewestein about the role of the German Federal Constitutional Court in the process of ratification of the EDC Treaty. ${ }^{15}$ Nevertheless, it is necessary to stress that writings focusing on NHCs were, at that time, clearly a minority in a general context in which the ECJ is the main focus of attention.

The second of the characteristics is the hegemony of legal-doctrinal studies aided by journals such as Common Market Law Review. Judicial actors were essentially considered the territory of lawyers. As stated by Dehousse, political science studies on European integration seemed for a long time to under-analyze the role of the Luxembourg Court. ${ }^{16}$ If that was the approach to the highest judicial institution of the communities, it is easy to guess that NHCs were simply ignored in this body of research. In fact, originally neither federalist theories, nor neo-functionalism or inter-governmentalism paid too much attention to judicial actors. As Burley and Mattli state, "The ECJ's accomplishments have long been the province only of lawyers, who either ignored or assumed their political impact. Beginning in the early 1980s, however, a small coterie of legal scholars began to explore the interaction between the court and the political institutions and processes of the EC." ${ }^{17}$ It was not until then that the studies in European integration began to take on the role of the courts.

According to Britta Redher ${ }^{18}$ it was in the mid-1980s-although the trend is more visible in the 1990s-when the number of studies devoted to judicial institutions in the process of

\footnotetext{
Executing Treaties and Community Law: A Pioneer Decision of the Court of Justice of the European Community, 67 AM. J. INT'L L. 504 (1973).

${ }^{14}$ See Aurelio Pappalardo, Decisions of the Italian Courts and the E.E.C. Treaty, 4 COMMON MKT. L. REV. 84 (1967); Evert Alkema, X v. Netherlands fiscal Administration: Netherlands Supreme Court, December 22, 1965, 4 COMMON MKT. L. ReV. 444 (1967); Mario Berri, Caisse d'aasurance regionale v. Torrekens. French Cour de Cassation (2e Chambre civile): Decision of December 1, 1965.41, 4 COMMON MкT. L. REV. 237 (1967).

${ }^{15}$ See Karl Loewestein, The Bonn Constitution and the European Community Treaties: A Study on Judicial Frustration, 64 YALE L.J. 805 (1955).

16 Renaud Dehousse, Integration Through Law Revisited: Some Thoughts on The Juridification of the European Political Process, in The Europeanisation of LAW: The Legal EfFECTS of European InTEgration 15 (Francis Snyder ed., 2000).

${ }^{17}$ Anne-Marie Burley \& Walter Mattli, Europe Before the Court: A Political Theory of Legal Integration, in DEBATES ON EUROPEAN INTEGRATION 226 (Mette Eilstrup-Sangiovanni ed., 2006).

18 Britta Redher, What is Political About Jurisprudence? Courts, Politics, and Political Science in Europe and the United States, in MPIFG DISCUSSION PAPER, MAX PLANCK INSTITUTE FOR THE STUdY OF SOCIETY 16 (2007).
} 
European integration started to multiply. Landmark analyses such as those by Weiler, Garret, or Burley and Mattli date back to this period. ${ }^{19}$ What happened at this stage was, fundamentally, that the two characteristics noted above started to blur. Although it of course continued to be one of the preferential objects of study in the field, ${ }^{20}$ the European Court of Justice no longer monopolizes scholarly attention. National courts-in fact, usually national lower courts-began to be studied, even if usually with regards to their relation to the ECJ, as curiosity increased about the use of the preliminary reference procedure ${ }^{21}$ or their reception of the constitutional principles of the EU such as of primacy and direct effect. ${ }^{22}$ In parallel, NHCs and their rulings also started to gain attention, especially by law scholars. Analyses of the Maastricht-Urteil ruling of the German Constitutional Federal Court and the Kompetenz-Kompetenz doctrine abounded. ${ }^{23}$ Subsequent sagas of rulings, such as

\footnotetext{
${ }^{19}$ See Joseph H.H. Weiler, The Transformation of Europe, 100 YALE L.J. 2403 (1991); Geoffrey Garret, International Cooperation and Institutional Choice: The European Community's Internal Market, 46 INT'L ORG. 533 (1992); AnneMarie Burley \& W. Mattli, Europe Before the Court: A Political Theory of Legal Integration, 47 INT'L ORG. 41 (1993); Geoffrey Garret, The Politics of Legal Integration in the European Union, 49 INT'L ORG. 171 (1995).
}

${ }^{20}$ Some of the most influential works on the court date back to this period. See, e.g., HJALTE RASMUSSEN, ON LAW AND Policy in the European Court of Justice: A Comparative Study IN JUdicial Policymaking (1986); Hjalte Rasmussen, Between Self-Restraint and Activism: A Judicial Policy for the European Court, 13 EUR. L. REV. 28 (1988); Mauro Cappelletti, Is the European Court of Justice Running Wild?, 12 EUR. L. REV. 4 (1987).

${ }^{21}$ See Alec Stone Sweet \& Thomas Brunell, Constructing a Supranational Constitution: Dispute Resolution and Governance in the European Community, 92 AM. POL. SCI. REV. 63 (1998); Jean-Yves Pitarakis \& George Tridimas, Joint Dynamics of Legal and Economic Integration in the European Union, 16 EUR. J. OF L. AND ECON. 357 (2003); Clifford Carruba \& Lacey Murrah, Legal Integration and Use of Preliminary Ruling Process in the European Union, 59 INT'L ORG. 399 (2005); Filippo Fontanelli \& Giuseppe Martinico, Between Procedural Impermeability and Constitutional Openness: The Italian Constitutional Court and Preliminary References to the European Court of Justice, 16 EUR. L.J. 345 (2010); Arthur Dyèvre, If You Can't Beat Them, Join Them: The French Constitutional Council's First Reference to the Court of Justice (Jeremy F. v. Premier ministre, 4 April 2013), 10 EUR. CONST. L. ReV. 154 (2014); Michal Bobek, Learning to Talk: Preliminary Rulings, the Courts of the New Member States and the Court of Justice, 45 Common Mkt. L. Rev. 1611 (2008); Aida Torres, Melloni in Three Acts: From Dialogue to Monologue, 10 Eur. CONST. L. REV. 308 (2014); François-Xavier Millet, How Much Lenience for How Much Cooperation? On the First Preliminary Reference of the French Constitutional Council to the Court of Justice, 51 COMMON MKT. L. REV. 195 (2014).

${ }^{22}$ Anne-Marie Slaughter, Alec Stone SWeet \& Joseph H.H. Weiler, The European Court And National Courts-Doctrine AND JURISPRUDENCE (1997)

${ }^{23}$ See Ulrich Everling, The Maastricht Judgement of the German Federal Constitutional Court and its Significance for the Development of the European Union, 14 Y.B. OF EUR. L. 1 (1994); Matthias Herdegen, Maastricht and the German Constitutional Court: Constitutional Restraints for an Ever Closer Union, 31 Common MKT. L. REV. 235 (1994); Steve Boom, The European Union After the Maastricht Decision: Will Germany Be the 'Virginia of Europe'?, 43 AM. J. CоMP. L. 177 (1995); Dieter Grimm, The European Court of Justice and National Courts: The German Constitutional Perspective After The Maastricht Decision, 3 ColuM. J. EUR. L. 229 (1996); MacCormick, supra note 9; Kevin Makowski, Solange III: the German Federal Constitutional Court's Decision on Accession to the Maastricht Treaty on European Union, 16 U. PA. J. INT'L BUS. L. 155 (1995); Karl M. Meessen, Hedging European Integration: the Maastricht Judgment of the Federal Constitutional Court of Germany, 17 FORDHAM INT'L L.J. 515 (1993); Weiler, supra note 9; Manfred Wiegandt, Germany's International Integration: The Rulings of the German Federal Constitutional Court on the Maastricht Treaty and the Out-of-Area Deployment of German Troops, 10 AM. U. INT'L L. REV. 889 (1995); 
those on the ratification process of the Lisbon Treaty ${ }^{24}$ or on the European Arrest Warrant, ${ }^{25}$ have been especially prolific in doctrinal reviews, thus consolidating the analysis of NHCs as one of the core aspects of European judicial integration studies.

At the same time, the second characteristic, the hegemony of legal-doctrinal approaches, is not only eroded, but rather becomes obsolete. ${ }^{26}$ Of course, doctrinal research continues to play an important role. And at the same time, European courts start to get the attention of social scientists, who approach them and their decisions from a different perspective, using as their starting point causal theories which they empirically test. Judicial politics literature is in this regard particularly important; during the late 1980s and the 1990s some of the most prominent scholars of the subdiscipline at the international level start to show an interest

Joachim Wieland, Kaleidoscope: Germany in the European Union-The Maastricht Decision of the Bundesverfassungsgericht, 5 EUR. J. INT'L L. 259 (1994).

${ }^{24}$ See Gunnar Beck, The Lisbon Judgement of the German Constitutional Court, the Primacy of EU Law and the Problem of Kompetenz-Kompetenz: A Conflict Between Right and Right in Which There Is No Praetor, 17 EUR. L.J. 470 (2011); Roland Bieber, 'An Association of Sovereign States' Comments on the German Constitutional Court's Decision on the Lisbon Treaty, 5 EUR. CONST. L. ReV. 391 (2009); Bríza, supra note 8 ; Erik O. Eriksen \& John E. Fossum, Bringing European Democracy Back In-Or How to Read the German Constitutional Court's Lisbon Treaty Ruling, 17 EUR. L.J. 153 (2011); Dieter Grimm, Defending Sovereign Statehood Against Transforming the European Union. Comments on the German Constitutional Court's Decision on the Lisbon Treaty, 5 EUR. CONST. L. REv. 353 (2009); Alfred Grosser, The Federal Constitutional Court's Lisbon Case: Germany's 'Sonderweg': An Outsider's Perspective, 10 German L.J. 1263 (2009); Philipp Kiiver, The Lisbon Judgment of the German Constitutional Court: A CourtOrdered Strengthening of the National Legislature in the EU, 16 EUR. L.J. 578 (2010); See supra note 8; Tobias Lock, Why the European Union is not a State. Some Critical Remarks: Comments on the German Constitutional Court's Decision on the Lisbon Treaty, 5 EUR. CONST. L. REV. 407 (2009); Matthias Niedobitek, The Lisbon Case of 30 June 2009-A Comment from the European Law Perspective, 10 GERMAN L.J. 1267 (2009); Schönberger, supra note 3; Frank Schorkopf, The European Union as An Association of Sovereign States: Karlsruhe's Ruling on the Treaty of Lisbon, 10 GERMAN L.J. 1219 (2009); Ivo Slosarcik, The Treaty of Lisbon \& the Czech Constitutional Court: Act II, CEPS POL. BRIEF 197/27 (2009); Christian Tomuschat, The Ruling of the German Constitutional Court on the Treaty of Lisbon, 10 German L.J. 1259 (2009); Ton Van den Brink, The Czech Constitutional Court and the Treaty of Lisbon, 3 TIJDSCHRIFT VOOR CONSTITUTIONEEL RECHT 315 (2010); Mattias Wendel, Lisbon Before the Courts: Comparative Perspectives, 7 EUR. CONST. L. ReV. 96 (2011); Christian Wohlfahrt, The Lisbon Case: A Critical Summary, 10 German L.J. 1277 (2009).

${ }^{25}$ See Christian Tomuschat, Inconsistencies-The German Federal Constitutional Court on the European Arrest Warrant, 2 EUR. CONST. L. ReV. 209 (2006); Angelika Nußberger, Poland: The Constitutional Tribunal on the Implementation of the European Arrest Warrant, 6 INT'L. J. CONST. L. 162 (2008); Nicolas Nohlen, Germany: The European Arrest Warrant Case, 6 INT'L. J. CONST. L. 153 (2008); Daniel Sarmiento, European Union: The European Arrest Warrant and the Quest for Constitutional Coherence, 6 INT'L. J. CONST. L. 171 (2008); Aida Torres, Constitutional Dialogue on the European Arrest Warrant: The Spanish Constitutional Court Knocking on Luxembourg's Door, 8 EUR. CONST. L. REV. 105 (2012).

${ }^{26}$ See Anne-Marie Slaughter \& Walter Mattli, The Role of National Courts in the Process of European Integration: Accounting for Judicial Preferences and Constraints, in THE EUROPEAN COURT AND NATIONAL COURTS-DOCTRINE AND JURISPRUDENCE 253 (Anne-Marie Slaughter, Alec Stone Sweet \& Joseph H.H. Weiler eds., 1997). 
for European courts. ${ }^{27}$ Political scientists like Karen Alter, ${ }^{28}$ Alec Stone Sweet, ${ }^{29}$ Walter Mattli, or Anne-Marie Slaughter ${ }^{30}$ made ground-breaking contributions to the understanding of European judicial politics. The "discovery" of European courts by political scientists, in addition, provoked subsequent changes in some of the grand narratives about European integration, which now put judicial actors at their core. Neo-functionalism was deeply revised and renewed, ${ }^{31}$ especially by Stone Sweet. Garret's neorealism ${ }^{32}$ was considered a new form of inter-governmentalism. ${ }^{33}$ In the area of legal scholarship, this is coupled with the tendency to go beyond purely legalist approaches, as is the case with Weiler's $\mathrm{s}^{34}$ influential writings and the general Law in Context literature as seen below.

\section{A Varied Disciplinary Background: Approaches to the Study of National Higher Courts}

As has been suggested above, at some point doctrinal approaches started to lose the monopoly of the study of judicial institutions in the process of European integration, especially as political scientists-and timidly also historians and sociologists-began to show interest in the subject. This varied disciplinary background constitutes probably one of the main riches of the subfield. Academics from different disciplines exhibit strongly different theoretical and methodological assumptions when studying NHCs. The subfield thus benefits from a variety of perspectives that contribute to a better understanding of the different

27 See generally MARY VolCANSEK, JUdiCIAL POLITICS IN EUROPE: AN IMPACt ANALYSIS (1986).

${ }^{28}$ Karen Alter, Explaining National Courts Acceptance of European Court Jurisprudence: A Critical Evaluation of Theories of Legal Integration, in THE EUROPEAN COURT AND NATIONAL COURTS-DOCTRINE AND JURISPRUDENCE 277 (AnneMarie Slaughter, Alec Stone Sweet \& Joseph H.H. Weiler eds., 1997). See also the work of other political scientists, e.g., Alec Stone Sweet \& Wayne Sandholtz, European Integration and Supranational Governance, 4 J. EUR. PUB. POL'Y 297 (1997); Wayne SANDholtz ANd Alec Stone SWEet, European InTEgration AND Supranational GovernanCE (1998); Stone Sweet and Brunell, supra note 22. For a review of this renewed form of neo-functionalism, see Wayne Sandholtz \& Alec Stone Sweet, Neo-Functionalism and Supranational Governance, in THE OXFORD HANDBOOK OF THE EUROPEAN UNION 18 (Erik Jones, Anand Menon \& Stephen Weatherill eds., 2012).

${ }^{29}$ See supra note 28 .

${ }^{30}$ Slaughter \& Mattli, supra note 27.

${ }^{31}$ See supra note 26.

32 See Garret, International Cooperation, supra note 19; Garret, The Politics of Legal Integration, supra note 19.

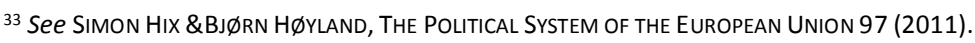

${ }^{34}$ Some of Weiler's pieces soon became landmark studies on European legal integration. See, e.g., Joseph H.H. Weiler, The Community System: The Dual Character of Supranationalism, 1 Y.B. OF EUR. L. 268 (1981); Weiler, supra note 19; Joseph H.H. Weiler, A Quiet Revolution: The European Court and its Interlocutors, 26 COMP. POL. STUD. 510 (1994); JOSEPH H.H. WEILER, EUROPA, FIN DE SIGLO (1995); Weiler, supra note 9; Joseph H.H. Weiler, European Neoconstitutionalism: In Search of Foundations for the European Constitutional Order, 44 POL. STUD. 517 (1996); JOSEPH H.H. Weiler, The CONStitution of Europe: ‘Do the NeW Clothes haVe AN EMPEROR?' AND Other ESSAYS ON EUROPEAN INTEGRATION (1999); Joseph H.H. Weiler, A Constitution for Europe? Some Hard Choices, 40 J. COMMON MARKET STUD. 563 (2002). Not all of these, however, explicitly take a Law in Context approach. 
facets of NHCs in the process of integration, such as the motivations behind their behavior, the legal content of their rulings, or the normative implications of their decisions. While the diversity of epistemological "languages" spoken by the different scholarly communities often complicate transdisciplinary dialogue, when this exists it proves extremely fruitful.

In this Section I will analyze separately these main approaches to the study of NHCs in the process of European legal integration, describing the internal dynamics of each of them.

\section{Legal-Doctrinal Approaches}

Literature on European judicial integration has used several categories to refer to the works made by law scholars using a doctrinal approach. Dyèvre ${ }^{35}$ has called them "formalpositivists," Karen Alter ${ }^{36}$ referred to them as "legalists," Weiler ${ }^{37}$ used the expression "formalists." Regardless, whatever label is chosen, it is not easy to clearly delimit the boundaries between this and other groups of studies. A reason is that works made by law scholars go clearly beyond mere doctrinal analyses of cases and incorporate into their narratives theoretical, political, or sociological reflections. ${ }^{38}$ Additionally, social science empirical research might potentially incorporate legal considerations and the specific rationality of the legal sphere into its description of judicial behavior, as Grimmel recently advocated. ${ }^{39}$ Tamanaha called studies which integrate legal variables into social science models "integrative approaches." ${ }^{0}$ These approaches, unfortunately, are still scarcely applied to the study of NHCs in the process of integration.

For the purposes of this Article, I propose applying the label of "legal-doctrinal" studies to that research which basically uses the tools and approach of doctrinal analysisinterpretation of the cases with reference to the legal system, clarification of the law, systematization of the decisions, and construction of a narrative which offers a coherent view of the legal system, or criticizes the lack of it. Stone Sweet summarized the state of affairs of these works as follows:

\footnotetext{
${ }^{35}$ Arthur Dyèvre, Making Sense of Judicial Lawmaking: A Theory of Theories of Adjudication, EUI WORKING PAPERS 2008/9 (2008).

${ }^{36}$ See Alter supra note 28.

${ }^{37}$ WEILER, THE CONSTITUTION OF EUROPE, supra note 34.

38 See Patricia Popelier, Armen mazmanyan \& Werner Vandenbruwaene, the role of Constitutional Courts in MULTileVel GovernANCE (2013).

${ }^{39}$ See Andreas Grimmel, Integration and the Context of Law: Why the European Court of Justice is not a Political Actor, Les CAHIERS EUROPÉENS DE SCIENCE Po 3/2011 1, 6 (2011).

40 Brian TAMANAha, ReAlistic Socio-Legal Theory (1997).
} 
Simplifying a great deal, two types of legal scholarship dominate the field: (a) doctrinal analyses of the ECJ's case law, and (b) doctrinal analyses of the reception of that case law by national courts. ... In the first . . . the approach implicitly assumes that there will be a crossnational unification of doctrine and practice, and treats resistance to constitutionalisation on the part of national judges as anomalous, deviant behaviour .... In the second, scholars assume that national law ... mediates the reception of EC law and the ECJ's jurisprudence. National deviance from the blueprint laid down by the European Court is treated as normal rather than pathological. ${ }^{41}$

Unlike social sciences research, the great majority of legal-doctrinal works do not offer an "explanatory" model of judicial behavior. Rather, doctrinal analyses usually comment on a ruling or set of rulings from a merely legal perspective. In these studies, the causes of judicial decision-making are simply left out of the analyses. Description and interpretation, rather than the exploration of causation, are the main aims of this type of research.

Doctrinal research on NHCs in the process of judicial integration reproduces some of the general peculiarities of legal scholarship. Unlike scientific disciplines, legal academia is still largely fragmented along national lines. ${ }^{42}$ This allowed the simultaneous development of different debates on the topic. On the one hand, debates in national scholar communities, which in some cases date back to rulings like Costa or the Internationale saga. On the other hand, a growing body of international literature, written mainly in English language, which has allowed the creation of a supranational, cross-border academic discussion on the topic. The national and supranational debates on NHCs have often been in close connection and have fed one another.

The national legal doctrine has shown a great interest for the rulings of the NHCs about European Union law. This has led to the creation of corpuses of literature confined to national borders which have fed debate in the national academia, or sometimes in the academia of certain linguistic areas. Although it is not my aim in this article to describe each of the national bodies of literature on NHCs and European integration, I would like to provide for at least a pair of examples. In France, the literature about the decisions of the French

\footnotetext{
${ }^{41}$ See Alec Stone Sweet, Constitutional Dialogues in the European Community, in THE EUROPEAN COURT AND NATIONAL COURTS-DOctrine AND JURISPRUdENCE 305, 309 (Anne-Marie Slaughter, Alec Stone Sweet \& Joseph H.H. Weiler eds., 2003).

${ }^{42}$ For a deeper reflection on the Europeanisation of legal scholarship, see the excellent contribution by Armin Von Bogdandy, National Legal Scholarship in the European Area-A Manifesto, 12 INT'L. J. ConST. L. 614 (2012).
} 
Constitutional Council regarding the European integration has been abundant. The importance of these decisions can be showed by the fact that they have been covered by some of the most prestigious national law journals, such as Revue Française de Droit Constitutionnel, and by authors such as Dutheillet de Lamothe or François Luchaire. ${ }^{43}$ Likewise, Spanish literature regarding the declarations of the Spanish Constitutional Court on EU treaties ${ }^{44}$ and on EU law in general ${ }^{45}$ has been significant. Indeed, Spanish authors such as López Castillo have also analyzed the rulings of other European NHCs. ${ }^{46}$ The interest over this topic can be illustrated by the existence of specialized publications in the country that cover EU constitutional law, such as Revista de Derecho Constitucional Europeo.

In parallel, the subfield has witnessed the creation of a corpus of legal-doctrinal literature fully internationalized. Although, of course, a number of earlier precedents can be found, especially Costa v. Enel, the outburst of this type of studies took place with occasion of some landmark cases such as the Solange saga or the Maastricht-Urteil ruling, which attracted the interest of leading jurists such as Grimm, Weiler, and MacCormick. ${ }^{47}$ The increasing attention paid by the international legal academia to these NHCs and their rulings seemed to crystallize in the first years of the twenty-first century in the creation of specialized academic publications such as European Constitutional Law Review, or semi-specialized ones like German Law Journal, which fostered the institutionalization of the subfield and stimulated further academic production. The processes of ratification of the major EU

${ }^{43}$ See Olivier Dutheillet de Lamothe, Le conseil constitutionnel et le droit européen, 57 REVUE FRANÇAISE DE DROIT COnstitutionnel 23 (2004); François Luchaire, Le Conseil Constitutionnel devant la Constitution pour l'Europe, 59 REVUE FRANÇAISE DE DROIT CONSTITUTIONNEL 465 (2004); Olivier Dupéré, Jurisprudence constitutionnelle, Le contrôle de constitutionnalité du droit dérivé de l'Union Européenne. Lectures croisées par le Conseil d'état et le Conseil Constitutionnel, 61 ReVUe FrançaISE de Droit CONStitutionnel 147 (2005); Guillaume Protière and Philippe Blachèr, Le Conseil Constitutionnel, gardien de la Constitution face aux directives communautaires, 69 REVUE FRANÇAISE DE Droit CONSTITUTIONnel 123 (2007); Florence Chaltiel, Droit constitutionnel européen, 82 REVUE FrançAISE DE DroIt CONSTITUTIONNEL 367 (2009); Maria R. Donnarumma, Intégration européenne et sauvegarde de l'identité nationale dans la jurisprudence de la Cour de justice et des Cours constitutionnelles, 84 REVUE FRANÇAISE DE DROIT CONSTITUTIONNEL 719 (2010).

44 Juan F. López Aguilar, Maastricht y la problemática de la reforma de la Constitución (Unión Europea, derechos de los extranjeros y reforma constitucional: teoría y case study), 77 REVISTA DE ESTUDIOS PolíTICOS 57 (1992); Manuel Aragón, La Constitución Española y el Tratado de la Unión Europea: la reforma de la Constitución, 42 REVISTA ESPAÑOLA DE DERECHO CONSTITUCIONAL 9 (1994).

${ }^{45}$ Juan Ignacio Ugartemendia \& Santiago Ripol, Continuismo y ¿novedad? En la doctrina del Tribunal Constitucional sobre el Derecho de la Unión Europea, 12 PAPELES DE DERECHO EUROPEO E INTEGRACIÓN REGIONAL (2012); Antonio López Castillo, La jurisprudencia iuscomunitaria del Tribunal Constitucional a doce años de la integración española en las Comunidades Europeas, 99 REVISTA DE ESTUDIOS PoLítICOS 189 (1998).

46 Antonio López Castillo, Entre europeización y germanización. De la mutante jurisprudencia del tribunal Constitucional Federal Alemán en perspectiva, 165 REVISTA DE ESTUdIOS PoLítICOS 117 (2014); Antonio López Castillo Prejudicializando ... Comentario de la primera cuestión prejudicial del Tribunal Constitucional Federal Alemán, 33 TEORía y REALIDAd CONSTITUCIONAL 315 (2014).

${ }^{47}$ See supra note 23 . 
treaties seem to have marked peaks of activity of this type of research. The Lisbon Treaty was commented in dozens of academic publications, including those by Eriksen and Fossum, Bŕiza, Beck, and Komárek, to mention just a few. ${ }^{48}$ The attention of the scholars focused in most cases on concrete decisions, ${ }^{49}$ with the Lisbon ruling of the Federal Constitutional Court of Germany being, by far, the most commented-on one within the group of decisions on this treaty. ${ }^{50}$ But also, together with single-case studies, some works have already started to transversally analyze sets of decisions, comparing the approaches of the courts, sometimes with certain openness to interdisciplinarity..$^{51}$ Finally, within this type of studies, the work of Claes deserves a special mention. Her 2006 book $^{52}$ provided for what probably is the most comprehensive review of the role of national courts in European integration carried out so far.

Evolution, therefore, points towards growing attention paid to NHCs within legal-doctrinal literature, both at the national and international level. It is remarkable, indeed, that the legal-doctrinal literature has been in quantitative terms the hegemonic approach to the study of the decisions of the higher courts of the Member States on European Union matters. Social science empirical research regarding these cases has traditionally been notably scarcer.

\section{Socio-Political Approaches}

By socio-politica $\left.\right|^{53}$ research, I refer to those studies that have been carried out using the theories, tools, and methodology of empirical social sciences, including both quantitative and qualitative analyses. Although it is possible to find instances of national socio-political research on NHCs in the process of European integration, ${ }^{54}$ social sciences literature on the

\footnotetext{
${ }^{48}$ See supra note 24.

${ }^{49}$ See, e.g., Bř́za, supra note 8; Slosarcik, supra note 24.

${ }^{50} \mathrm{See}$, e.g., Julio Baquero, A Judicial Götterdämmerung. The Lisbon Decision of the German Constitutional Court, in KARLRUHE'S EUROPE 78 (Katrin Auel \& Julio Baquero eds., 2009); Bieber, supra note 24; Grimm, supra note 24; Grosser, supra note 24; Kiiver, supra note 24.

51 See Wojciech Sadurski, 'Solange, Chapter 3': Constitutional Courts in Central Europe-Democracy-European Union, 14 EUR. L.J. 1 (2008); Wendel, supra note 24; Tajtana Evas \& Ulrike Liebert, Enhancing Democratic Legitimacy Through Constitutional Pluralism? The Czech, German and Latvian Lisbon Rulings in Dialogue, in MULTILAYERED RePresentation IN THE EUROPEAN UNION 107 (Tajtana Evas, Ulrike Liebert \& Christopher Lord eds., 2012); Pablo J. Castillo Ortiz, Playing the Judicial Card. Litigation Strategies During the Process of Ratification of the Lisbon Treaty, 20 EUR. L.J. 630 (2014).

52 See Monica Claes, The national Courts Mandate in the European Constitution (2006).

${ }^{53}$ See Dyèvre, supra note 35.

${ }^{54}$ See Juan A. Mayoral, La politización de la aplicación judicial del derecho europeo: un estudio del Tribunal Supremo Español, 161 ReVISTA De Estudios Polítıcos 117 (2013); Pablo J. Castillo Ortiz, La Política Judicial del Tribunal
} 
topic was from the outset largely internationalized. This body of research approached European judicial integration from socio-political perspectives, not only developing solid and sophisticated theoretical models, but also testing them empirically.

Although a few instances of sociological works can be found, ${ }^{55}$ judicial politics research has had a protagonist role within this group of studies. As stated above, in the 1990s a number of specialists in this subdiscipline started to show interest for European courts. Unfortunately, some of them did not approach NHCs in detail, as is the case of Garret's neorealist model. ${ }^{56}$ Although Garret at some point integrates "domestic courts" into his narrative, and even if he briefly refers to the relations between NHCs and the ECJ, ${ }^{57}$ his analysis focuses on the later actor. ${ }^{58}$ Karen Alter $^{59}$ and Alec Stone Sweet ${ }^{60}$ paid more attention to NHCs. Although Alter focused more on inter-court dynamics while Stone Sweet analyzed the relation between judicial actors and the general process of integration, both seemed to agree on a number of aspects. They both considered that different judicial actors had different interests vis-à-vis European integration, so that NHCs were in general losers in the new scenario. ${ }^{61}$ National lower courts had been empowered by EU law and by their relation to the ECJ. They often had an incentive to refer cases to Luxembourg, and through these references the ECJ could develop its "constitutional" doctrines. And with such doctrines, NHCs were disempowered. This would explain the resistance by judicial institutions such as the German Federal Constitutional Court, which accepted the new "constitutional" principles of EU law but grounded in and limited by its own national

\footnotetext{
Constitucional español en los procesos de ratificación de Tratados de la Unión Europea: aproximación desde un nuevo realismo jurídico, 159 REVISTA DE ESTUDIOS PoLítICOS 107 (2013).

${ }^{55}$ Unfortunately, sociological works about the topic are still scarcer than political science ones. These are usually pieces that either just mention NHCs incidentally, or use sociological approaches only to a certain extent, combined with other disciplinary perspectives. See, e.g., Antonin Cohen \& Antoine Vauchez, The Social Construction of Law: The European Court of Justice and Its Legal Revolution Revisited, 7 ANN. REV. OF L. \& Soc. SCI. 417 (2011); Antoine Vauchez, The Transnational Politics of Judicialization. Van Gend en Loos and the Making of EU Polity, 16 EUR. L.J. 1 (2010); Jiří Přibáň, Multiple Sovereignty: On Europe's Self-Constitutionalization and Legal Self-Reference, 23 RATIO JURIS 41 (2010).

${ }^{56}$ See Garret, International Cooperation, supra note 19; Garret, The Politics of Legal Integration, supra note 19; Geoffrey Garret \& Barry Weingast, Ideas, Interests and Institutions: Constructing the Ecs Internal Market, in IDEAS AND FOREIGN POL'Y 173 (Judith Goldstein \& Robert Keohane eds., 1993).

${ }^{57}$ See Garret, The Politics of Legal Integration, supra note 19, at 174.

${ }^{58}$ Stone Sweet criticized the model by suggesting that "nothing in it helps to understand ECJ-national court interaction." Stone Sweet, supra note 41, at 310.

${ }^{59}$ Alter, supra note 28.

${ }^{60}$ See id., supra note 28.

${ }^{61}$ See Alter, supra note 28, at 242; Alec Stone SWeet, The Judicial Construction of Europe 22 (2004).
} 
constitution. ${ }^{62}$ In addition, it is worth mentioning the model developed by Slaughter and Mattli, ${ }^{63}$ which also relied on the idea of judicial empowerment. In their piece, the authors develop a model to explain the behavior of national courts in the process of integration, combining incentives-willingness to gain or keep powers of judicial review, maximization of power and prestige vis-à-vis other national courts, and power to promote substantive policies-and constraints - the requirements of the legal discourse and, at the same time, democratic accountability. One of the most appealing aspects of this model is probably that it gives an important role to juridical factors and to the self-understanding of courts as legal actors.

Interestingly, most of the models mentioned above have a couple of things in common. First, many of them refer to self-empowerment as one of the basic explanatory accounts of judicial behavior. Mattli and Slaughter recalled that this idea was borrowed from Joseph Weiler, ${ }^{64}$ showing the early emergence of cross-disciplinary dialogue in the field. Second, these studies did not focus exclusively on NHCs. In the best cases, the higher courts of the Member States were just one more of the actors to be scrutinized as part of the larger phenomenon of European judicial integration. Often, the protagonist was still the European Court of Justice.

The wave of socio-political research born in the 1990s has been for decades the mainstream reference in social sciences studies of European courts. And it still is. Only in the last years, a new body of socio-political studies with NHCs as the absolute protagonists has timidly started to emerge. Of course, NHCs have continued to be researched as part of more general studies about judicial institutions in the European Union, ${ }^{65}$ and in some cases the impact of the process of European integration over these institutions has been analyzed. ${ }^{66}$ But together with this, some pieces of research have started to focus mainly on NHCs and their decisions on EU law. A line of research lead by Closa has analyzed NHCs' decisions on EU treaties, explaining their behavior from neo-institutional assumptions and depicting them as strategic, cost-avoiding actors. ${ }^{67}$ Additionally, using both quantitative ${ }^{68}$ and game-

\footnotetext{
62 See Alter, supra note 28, at 64; Stone Sweet, supra note 41, at 327.

63 Slaughter \& Mattli, supra note 26.

${ }^{64}$ See Slaughter \& Mattli, supra note 26, at 258.

65 See Frank Schimmelfenning, Competition and Community: Constitutional Courts, Rhetorical Action, and the Institutionalization of Human Rights in the European Union, 13 J. EUR. PUB. PoL'y 1247 (2006); J.A. Mayoral, U. Jaremba \& T. Nowak, Creating EU Law Judges: The Role of Generational Differences, Legal Education and Judicial Career Paths in National Judges' Assessment Regarding EU Law Knowledge, 21 J. EUR. PUB. POL'Y 1120 (2014).

${ }^{66}$ See Nicola CORKIN, EUROPEANIZATION Of JUdiCIAL REVIEW (2015).

${ }^{67}$ See Closa \& Castillo Ortiz, supra note 10; Closa, supra note 10; CASTILLO ORTIZ, supra note 10.

${ }^{68}$ See Dyèvre, European Integration and National Courts, supra note 11.
} 
theoretical approaches, ${ }^{69}$ Dyèvre has made a number of significant contributions to the causal understanding of the attitude of these institutions vis-à-vis the European Court of Justice and its doctrine. This new wave of research shows the existence of a trend towards the consolidation of the study of NHCs in the process of European integration, also in the disciplines of the social sciences, and more specifically in political science.

\section{Beyond Legal and Social Sciences Positivisms}

There are, yet, a number of studies which can hardly be included in any of the two former categories. These studies are so diverse that they cannot be said to actually form an individual group, although many of them share the aim to offer accounts of European judicial integration which go beyond the positivist approaches in law or social sciences. Frequently, these studies have been very ambitious from a theoretical or philosophical perspective. Although many of them have been carried out by law scholars, they all go beyond the boundaries of purely "legalistic" research. They often combine legal and political considerations, exhibiting a certain taste for interdisciplinary and, specifically, for transdisciplinary dialogue. Some of them are heterodox legal studies which incorporate political or power-related reflections into their analysis, such as the early work of Stein or the more recent one by Bobek. ${ }^{70}$ Others are "soft" political studies that analyze judiciaries without adhering to a strict positivist approach, like Dyèvre's recent comment on Karlsruhe's Lisbon decision. ${ }^{71}$ Additionally, authors such as Von Bogdandy, Komarek, or Petkova have enriched the subfield with works which approach NHCs from the perspective of legal and/or political theory ${ }^{72}$ while Rasmussen, Davies, and others have made important contributions from the perspective of legal history. ${ }^{73}$

\footnotetext{
${ }^{69}$ See Dyèvre, Judicial Non-Compliance, supra note 11.

70 The early work by Stein can be seen as an outstanding example of interdisciplinary work. Eric Stein, Lawyers, Judges, and the Making of a Transnational Constitution, 75 AM. J. INT'L L. 1 (1981). More recently, see the more laworiented work by Michal Bobek. The Impact of the European Mandate of Ordinary Courts on the Position of Constitutional Courts, in Const. Conversations In EUR. 287 (Monica Claes, Maartje de Visser, Patricia Popelier \& Catherine Van de Heyning eds., 2012).

${ }^{71}$ See Arthur Dyèvre, The German Federal Constitutional Court and European Judicial Politics, 34 WEST EUR. POL. 346 (2011); Castillo Ortiz, supra note 51.

${ }^{72}$ See Jan Komarek, National Constitutional Courts in the European Constitutional Democracy, 12 INT'L. J. ConST. L. 525 (2014); Jan Komarek, The Place of Constitutional Courts in the EU, 9 EUR. CONST. L. REV. 420 (2013). Sometimes the reflection has been expanded to other contexts. See Armin Von Bogdandy, Pluralism, Direct Effect, and the Ultimate Say: On the Relationship Between International and Domestic Constitutional Law, 6 INT'L. J. CONST. L. 397 (2008); Bilyana Petkova, The Notion of Consensus as a Route to Democratic Adjudication?, 14 CAMBRIDGE Y.B EUR. LEGAL STUD. 663 (2011-2012).

73 See, e.g., Morten Rasmussen, Rewriting the History of EPL: The New Contribution of Historians, 28 AM. U. L. REV. 1187 (2013); BILL DAVIES, RESISTING THE ECJ: WeSt GeRMANY's ConfrontaTION WITH EUROPEAN LAW, 1949-1979 (2012); Bill Davies, Pushing Back: What Happens When Member States Resist the European Court of Justice? A Multi-Modal
} 
In addition to this general landscape, there are two streams of literature which cannot be considered as purely doctrinal or socio-political either, but which have a certain internal homogeneity in their theoretical or epistemological approaches and which have had an enormous impact in the subfield. These are the Law in Context research and, closely related to it, the constitutional pluralism literature. In both of them, the analysis and discussion of NHCs and their decisions has played a core role, thus inspiring further research on these institutions.

One of the most important branches of literature in general European judicial integration is that of Law in Context studies. The defining feature of this stream of research is its approach to the study of legal phenomena, which goes beyond exclusively legal considerations. This sui generis approach has been boosted by some of the leading publications in the field, such as European Law Journal, which defines itself as a "Review of European Law in Context." In this regard, Mattli and Slaughter praised law scholars such as Stein, Snyder, Shapiro, Rasmussen, and Weiler for "pushing European and American lawyers away from strictly doctrinal analyses of EC law." ${ }^{74}$ Indeed, the main reference in Law in Context approaches is commonly the work of Joseph Weiler. Weiler aimed at analyzing "the Community constitutional order with particular regard to its living political matrix," ${ }^{75}$ and his analyses of the relationship between national courts and the ECJ have been, as recognized by Stone Sweet, enormously influential on further social science research. ${ }^{76}$ NHCs played an important role in the work of Weiler, who offered insightful explanations of their acceptance of the doctrines of the European Court of Justice ${ }^{77}$ as well as of the limits they set to it, ${ }^{78}$ to mention just a pair of examples. Subsequent work on NHCs has also used a Law in Context Approach. Sadurski analysis of the position on EU law matters of the NHCs of Central European Member States, ${ }^{79}$ Baquero's famous article on the legacy of the Maastricht-Urteil

\footnotetext{
Approach to the History of European Law, 21 CONTEMP. EUR. HIST. 417 (2012); Mark Pollack, The New EU Legal History: What's New, What's Missing, 28 AM. U. INT'L L. REV. 1257 (2013).

${ }^{74}$ Walter Mattli \& Anne-Marie Slaughter, Constructing the European Community Legal System from the Ground Up: The Role of Individual Litigants and National Courts (1996), www.jeanmonnetprogram.org/archive/papers/96/9606ind.html (last visited Mar. 23, 2015).

${ }^{75}$ Weiler, supra note 19 , at 2409.

${ }^{76}$ See Alec Stone Sweet \& Thomas Brunell, The European Court and the National Courts. A Statistical Analysis of Preliminary References, 1961-95, 5 J. EUR. PUB. POL'Y 66, 69 (1998).

77 See WeILER, THE CONSTITUTION OF EUROPE, supra note 34, at 32.

${ }^{78}$ See Weiler, A Constitution for Europe?, supra note 34.

${ }^{79}$ See Sadurski, supra note 51.
} 
decision, ${ }^{80}$ or more recently, Deter's work on the ESM ruling of the German court are magnificent examples of the vitality of this type of scholarship. ${ }^{81}$

In parallel to the Law in Context approach, and on occasions in clear connection with it, there exists a group of studies rooted in legal theory and generally referred to as constitutional pluralism literature. This body of research has provided for very valuable theoretical tools to understand European integration. In pluralists' approaches, legal analyses are sometimes intertwined with political considerations, but the emphasis is usually on the theoretical dimension of law. Among them, the work of MacCormick must be highlighted. The pieces of the Scottish legal philosopher on the Maastricht-Urteil decision of the Federal Constitutional Court of Germany ${ }^{82}$ are still a reference in the subfield two decades later. Neil MacCormick's work addressed the new normative structure emerging from the development of the European legal system in parallel to national legal systems, conceptualizing the heterarchical coexistence of both legal systems in terms of constitutional pluralism. This idea of constitutional pluralism has been prolifically echoed in further research of legal ${ }^{83}$ or interdisciplinary ${ }^{84}$ character about the European Union, with NHCs being often at the core of this type of analysis. The inspiration of the ideas of MacCormick, as well as their discussion, can still be found in the latest wave of works in European legal theory, such as the recent studies by Fossum and Menendez ${ }^{85}$ or Giuseppe Martinico. ${ }^{86}$

\footnotetext{
${ }^{80}$ See Baquero, supra note 3.

${ }^{81}$ See Henning Deters, National Constitutional Jurisprudence in a Post-National Europe: The ESM Ruling of the German Federal Constitutional Court and the Disavowal of Conflict, 20 EUR. L.J. 204 (2014).

82 See MacCormick, supra note 9; Neil MacCormick, Democracy, Subsidiarity, and Citizenship in the European Commonwealth, 16 L. AND PHIL. 331 (1997).

${ }^{83}$ See Neil Walker, The Idea of Constitutional Pluralism, 65 Mod. L. Rev. 317 (2002); N. Walker, Reconciling MacCormick: Constitutional Pluralism and the Unity of Practical Reason, 24 RATIO JURIS 369 (2011); Nicholas W. Barber, Legal Pluralism and the European Union, 12 EUR. L.J. 306 (2006); Miguel Maduro, A constituçao PluralConstitucionalismo e União Europeia (Principia 2006); Miguel Maduro, Interpreting European Law-Judicial Adjudication in a Context of Constitutional Pluralism (IE Law School, Working Paper No. WPLS08-08, 2008); Giuseppe Martinico, Multiple Loyalties and Dual Preliminarity: The Pains of Being a Judge in a Multilevel Legal Order, 10 INT'L. J. CONST. L. 871 (2012).

${ }^{84}$ See Evas \& Liebert, supra note 51.

${ }^{85}$ See John E. Fossum \& Agustín J. Menéndez, The Constitution’s Gift (2011).

${ }^{86}$ See Giuseppe Martinico, The Tangled CompleXity of the EU Constitutional Process: The Frustrating Knot of Europe (2013).
} 


\section{A Diversified Research Agenda: Topics and Issues for Studying National Higher Courts}

In the previous section I argued that studies of NHCs in the process of European integration can be classified into different disciplinary categories, which have their own internal dynamics and display different theoretical assumptions. Yet, in this section I shall argue that all of these different streams have converged in the analysis of a number of concrete objects of study. While the common focus on specific topics has by no means meant the "unification" of the subfield, it has at least provided for increasing cross-disciplinary dialogue, sometimes institutionalized through workshops, interdisciplinary research groups, etcetera. Clear disciplinary divides remain, but scholars have shown curiosity and a certain willingness to engage with the work of their colleagues from other disciplines.

\section{NHCS and Ratification of EU Treaties}

A first thematic approach has analyzed the rulings of NHCs in processes of ratification of EU Treaties. These cases are salient at least for two reasons. First, because these rulings give NHCs the chance to participate in the process of creation of European Union primary law, which has enormous legal and political implications. Second, because some of these rulings became essential landmarks of the so-called judicial dialogue with the ECJ. Among the pieces approaching these rulings both legal and political ones can be found. Legal works such as those by MacCormick, Meessen, Rasmussen, or Lachmann have focused in individual rulings ${ }^{87}$ although Wendel provides for an excellent example of legal comparative analysis of different rulings. ${ }^{88}$ Indeed, such comparative analyses have sometimes been carried out from an interdisciplinary perspective. ${ }^{89}$ Political science research on these cases is relatively scarcer. Nonetheless, as stated above, there is a clearly identifiable research line whose core claim is the idea that NHCs made a calculation of costs and risks for ratification when making their decisions on EU treaties, ${ }^{90}$ sometimes defended from a cross-disciplinary perspective. ${ }^{91}$ Finally, it is worth noting that rulings on accession treaties, which can be

\footnotetext{
${ }^{87}$ See, e.g., Meessen, supra note 23; MacCormick, supra note 9; Per Lachmann, The Treaty of Maastricht vs. the Danish Constitution, 68 NORDIC J. INT'L L. 365 (1998); Hjalte Rasmussen, Confrontation or Peaceful Co-existence? On the Danish Supreme Court's Maastricht Ratification Judgment, in JUDICIAL REVIEW IN EUROPEAN UNION LAW 377 (David O’Keeffe ed., 2000); Lock, supra note 24; Bříza, supra note 8.

${ }^{88}$ See Wendel, supra note 24.

${ }^{89}$ See Castillo Ortiz, supra note 51.

${ }^{90}$ See Closa \& Castillo Ortiz, supra note 10.

${ }^{91}$ See Castillo Ortiz, supra note 10.
} 
considered as a special type of rulings on EU treaties, have also sometimes attracted a certain interest in the subfield, as showed by the work of Sadurski and Kowalik-Banczyk. ${ }^{92}$

\section{NHCs and Other Decisions on EU Law}

In addition to their decisions on EU Treaties NHCs have issued other important rulings with implications for EU law, such as those on implementing legislation. The merits of these rulings have been more often the object of attention of law scholars, while political scientists have approached them as part of their analysis of other topics, such as the relations with the Court of Justice as seen below. Among doctrinal analyses, and beyond case studies of one particular ruling, two basic approaches can be identified. First, pieces such as that of Pollicino which make a general review of the case law of a particular court on EU law matters, which generally aim at identifying the "attitude" of such institution towards European integration and the European legal system. ${ }^{93}$ Second, studies reviewing sagas of decisions, such as those on the European Arrest Warrant. ${ }^{94}$ Finally, one of the most promising trends in the field are the recent works comparing and analyzing the general approach to EU law of a number NHCs, such as those of Albi and Wendel. ${ }^{95}$ Furthermore, Evas provides for an interesting instance of how this can be done from an interdisciplinary approach. ${ }^{96}$

\section{Judicial Dialogue, Judicial Conflict}

The relations between NHCs, the ECJ and sometimes also the ECtHR have been one of the preferential objects of attention of scholars. On the one hand, NHCs have been protagonists of analyses for their preliminary references to the ECJ-or lack thereof. On the other hand, the rulings of the higher courts of Member States such as Germany, Denmark, or Poland

92 Krystyna Kowalik-Banczyk, Should We Polish It Up/The Polish Constitutional Court and the Idea of Supremacy of EU Law, 6 GERMAN L.J. 1355 (2005); Sadurski, supra note 51.

${ }^{93}$ See, e.g., Oreste Pollicino, The Relationship Between the National Legal Order and the European Legal Order in the Case Law of the Italian Constitutional Court: A Selection of the Most Recent Relevant Decisions, ITALIAN Y.B. INT'L L. 323 (2011-2012); Kowalik-Banczyk, supra note 92.

${ }^{94}$ See Jan Komarek, European Constitutionalism and the European Arrest Warrant: In Search of the Limits of 'Contrapunctual Principles,' 44 Common MKT. L. ReV. 9 (2007); Massimo Fichera, The European Arrest Warrant and the Sovereign State: A Marriage of Convenience?, 15 EUR. L.J. 70 (2008).

${ }^{95}$ Sometimes these works include the analysis of both decisions on EU treaties and other decisions related to EU law. See Anneli Albi, Selected EU Judgments by CEE Constitutional Courts: Lessons on How (Not) to Amend Constitutions?, 3 CROATIAN Y.B. OF EUR. L. AND POL'Y 39 (2007); Anneli Albi, From the Banana Saga to a Sugar Saga and Beyond: Could the Post-Communist Constitutional Courts Teach the EU a Lesson in the Rule of Law?, 47 COMMON MKT. L. REv. 791 (2010); Mattias Wendel, Comparative Reasoning and the Making of a Common Constitutional Law: EU-related Decisions of National Constitutional Courts in a Comparative Perspective, 11 INT'L. J. ConST. L. 981 (2013).

${ }^{96}$ See tatjana evas, Judicial Application of European Union law in Post-Communist Countries: The Cases of Estonia AND LATVIA (2012). 
have been widely discussed as they have set a number of exceptions to the unlimited primacy of EU law, based on the idea of ultra-vires review, the defense of national constitutional rights, or the protection of core constitutional provisions. Both lawyers and political scientists have made a significant effort to analyze this topic, although the perspectives employed by both of them have been generally divergent. In general, law scholars have used more theoretically-driven approaches and emphasized the mechanisms of formal and informal cooperation between NHCs and the ECJ. ${ }^{97}$ Pluralist conceptions of law in the context of European integration have had a leading role in this type of analysis, ${ }^{98}$ and the sweetening concept of "judicial dialogue" 99 has been used to frame inter-court relations. Yet, the theoretical emphasis on cooperation in doctrinal pieces has not avoided concessions to the idea that conflict underlies relations between courts in the process of "judicial integration," 100 especially in the situations in which such conflict has been more explicit. ${ }^{101}$ Political science narratives, in contrast, were constructed around this idea of conflict. This sector of the literature has tried to understand the reasons behind such conflict with the idea of self-empowerment playing a core role. ${ }^{102}$ These different emphases in cooperation and conflict are probably the crystallization of the different epistemological and theoretical assumptions of both disciplines, although fortunately the interactions in the field

97 See, e.g., Armin von Bogdandy \& Schill Stephan, Overcoming Absolute Primacy: Respect for National Identity Under the Lisbon Treaty, 48 Common MKT. L. ReV. 1 (2011); Darinka Piqani, The Role of National Constitutional Courts in Issues of Compliance, in COMPLIANCE AND THE ENFORCEMENT OF EU LAW 132 (Marise Cremona ed., 2012); Darinka Piqani, Arguments for a Holistic Approach in European Constitutionalism: What Role for National Institutions in Avoiding Conflicts Between National Constitutions and EU Law?, 8 EUR. CONST. L. ReV. 493 (2012). Kumm and Ferreres also emphasized the possibilities that the Constitutional Treaty offered to channel judicial conflict. See Mattias Kumm \& Victor Ferreres, The Primacy Clause of the Constitutional Treaty and the Future of Constitutional Conflict in the European Union, 3 INT'L. J. CONST. L. 473 (2005).

98 See Miguel maduro, We the Court: The European Court of Justice and the European Economic Constitution: A CRItICAL ReAding of ARTICLE 30 EC 30 et seq. (1998).

99 Christiaan Timmermans, The Pluralist, Multilevel/Multiplayer Approach and the Primacy Principle, in CONStitutionalising the EU JUd. Sys.: EsSAYs In HONOUR Of Pernilla LindH 15 (Pascal Cardonnel, Allan Rosas \& Nils Wahl eds., 2012); Allan Rosas, The European Court of Justice in Context: Forms and Patterns of Judicial Dialogue, 1 EUR. J. LEGAL STUD. 1 (2007); Pollicino, supra note 94. Please note that despite the connotations of the concept, many of the authors framing inter-court relations in terms of "dialogue" acknowledge also, to different extents, the existence of conflict.

100 Barber, supra note 83 , at 306.

101 See Michal Bobek, Landtová, Holubec, and the Problem of an Uncooperative Court: Implications for the Preliminary Rulings Procedure, 10 EUR. CONST. L. ReV. 54 (2014); Jan Komarek, Playing with Matches: The Czech Constitutional Court Declares a Judgment of the Court of Justice of the EU Ultra Vires, 8 EUR. CONST. L. REV. 323 (2012).

102 See Alter, supra note 28; Dyèvre, European Integration and National Courts, supra note 11; Dyèvre, Judicial NonCompliance, supra note 11; CASTILLO ORTIZ, EU TREATIES, supra note 10. 
have allowed for a modicum of dialogue in these regards, showing the great awareness in both sides about the work of colleagues from the other discipline. ${ }^{103}$

\section{NHCs and the Euro-Crisis}

Finally, the recent economic-and political-crisis of the European Union has been the context for a number of rulings by NHCs with important implications for European integration. Among these, rulings on the mechanisms of financial assistance, ${ }^{104}$ as well as those on austerity measures, ${ }^{105}$ have received the attention of, inter alia, Beck, Schmidt, or Fasone. Rulings on mechanisms of assistance-usually called bailouts-can be considered a special subtype of decisions on EU Treaties, although with important specificities. A good example is the ESM treaty, which is not formally a treaty of the EU and whose process of ratification did not require consensus of all Member States, as De Witte and Beukers recall. ${ }^{106}$ Likewise, rulings on austerity measures can be considered close to decisions on general EU law, although in this case the differences are even more notable. Austerity measures were adopted by the Member States often at the instances of actors which had a clear relation to the process of integration, but which were acting outside the EU legislative and decision-making procedures-the so-called troika. NHCs' decisions dealing with the Euro-crisis, including the first reference of the German Federal Constitutional Court to the $E C J,{ }^{107}$ show the special moment that the European Union is going through. While most analyses of these decisions have been essentially doctrinal in character, pieces such as Fabbrini's recent article have a clear interdisciplinary flavor. ${ }^{108}$

\footnotetext{
${ }^{103}$ See Komarek, supra note 72, at 422; Komarek, supra note 101, at 324, Dyèvre, European Integration and National Courts, supra note 11 , at 142 .

104 Mattias Wendel, Judicial Restraint and the Return to Openness: The Decision of the German Federal Constitutional Court on the ESM and the Fiscal Treaty of 12 September 2012, 14 GeRMAN L.J. 21 (2013); Susanne Schmidt, A Sense of Déjà Vu? The FCC's Preliminary European Stability Mechanism Verdict, 14 GerMAN L.J. 1 (2013); Karsten Schneider, Yes, But... One More Thing: Karlsruhe's Ruling on the European Stability Mechanism, 14 GERMAN L.J. 53 (2013); Gunnar Beck, The Court of Justice, the Bundesverfassungsgericht and Legal Reasoning During the Euro Crisis: The Rule of Law as a Fair-Weather Phenomenon, 20 EUR. PUB. L. 539 (2014); Elaine Fahey \& Samo Bardutzky, Judicial Review of Eurozone Law: The Adjudication of Postnational Norms in the EU Courts, Plural-A Case Study of the European Stability Mechanism (Amsterdam L. School Legal Stud. Research Paper No. 2013-35, 2013); Deters, supra note 81.

${ }^{105}$ See Fasone, supra note 7.

106 See Bruno de Witte \& Thomas Beukers, The Court of Justice Approves the Creation of the European Stability Mechanism Outside the EU Legal Order: Pringle, 50 CommOn MKT. L. Rev. 805 (2013).

107 See Mattias Wendel, Exceeding Judicial Competence in the Name of Democracy: The German Constitutional Court's OMT Reference, 10 EUR. CONST. L. REV. 263 (2014).

${ }^{108}$ See Federico Fabbrini, The Euro-Crisis and the Courts: Judicial Review and the Political Process in Comparative Perspective, 32 BERKELEY J. INT'L L.64 (2014).
} 
These four topics, of course, do not exhaust the range of issues addressed by academics when studying the role of NHCs in the process of European integration, but they probably constitute the most salient ones. For all of them, examples of inter-disciplinary work or cross-disciplinary dialogue have been provided. By attracting the attention of scholars from different disciplines around a topic placed in the boundary between the national and the supranational, the analysis of NHCs in the process of integration has become a unique site for fruitful academic production.

\section{E. Conclusions}

One of the most striking features of seminal studies is that they often advance the features that the whole field that they are creating will display in the future. This is precisely the case with the piece entitled The Bonn Constitution and the European Community Treaties. A Study on Judicial Frustration, which Karl Loewestein wrote about the role of the German Federal Constitutional Court in the process of ratification of the European Defense Community Treaty. ${ }^{109}$ First, as said before, this work was one of the earliest analyses about NHCs in the process of European integration, a subfield which decades later shows a notable degree of autonomy and consolidation. Second, the German academic, who was forced to exile from his homeland during the Nazi period, published his work in English in the distinguished The Yale Law Journal, making it accessible to a wider community beyond that of the country in which the ruling had been issued. Internationalization would become, with the years, one of the structuring features of the subfield. And third, the study is an extraordinary example of inter-disciplinary work. Loewestein's research often combined law and politics, and this piece was no exception to the general rule. Indeed, the description of courts as strategic actors, which the author uses to depict the German court, has been one of the core ideas of works in the subfield for decades.

Surprisingly, subsequent pieces on NHCs in the process of integration have not often acknowledged the foundational character of this early work, which might still remain unknown to many. And yet, six decades later its seed has germinated, giving rise to a subfield which attracts the interest of world-leading academics. The higher courts of the Member States and the role they play in the EU are essential to understanding Law in Context literature and constitutional pluralism theories. The subfield is the site where the interests of lawyers and political scientists converge, and where theorists and empiricist engage in dialogue. Rulings such as Crotty or Maastricht-Urteil are not accidents. They are the result of the institutional design of the European political edifice as well as the consequence of the constitutional architectures of Member States, which allow higher courts to be easily "invited" to participate in the discussion about the European Union. Because everything points at these institutional and constitutional elements remaining stable in the future, the

${ }^{109}$ Loewestein, supra note 15. 
contributions of the subfield will continue to be essential to our correct understanding of the process of integration. 